\title{
UKRAINIAN QUESTION IN THE PROLETKULT ACTIVITY
}

\begin{abstract}
The article highlights the social and political conditions under which the proletarian educational organizations of the 1920s functioned in the context of nationality issue, namely the study of political frameworks determining the status of the Ukrainian language and culture in Ukraine. The nationality issue became crucial in Proletkult activities - a proletarian cultural, educational and literary organization in the structure of People's Commissariat, the aim of which was a broad and comprehensive development of the proletarian culture created by the working class. Unlike Russia, Proletkult's organizations in Ukraine were not significantly spread and ceased to exist due to the fact that the national language and culture were not taken into account and the contact with the peasants and indigenous people of nonproletarian origin was limited.

Keywords: Proletkult, worker, culture, language, policy, organization.
\end{abstract}

Formulation of the problem. Contemporary social transformations require detailed, critical reinterpreting the experiences of previous generations. In his work "Lectures" Hegel wrote that experience and history taught that peoples and governments had never learnt from history and did not act in accordance with the lessons that history could give. The objective study of Russian-Ukrainian relations require special attention that will help to clarify the reasons for misunderstandings in historical context, to consider them in establishing intercommunication and ensuring peace in the geopolitical space.

The period of interest is $20-30$ years of the $20^{\text {th }}$ century time of intensive cultural development, showing tendency to democracy, creativity, and diversity. However, it remained tendentiously presented by official Soviet pedagogical science when the complex and ambiguous process was adjusted to wellknown results in advance (Sukhomlynska, 1996, 7). The article proposes the study of the Russian-Ukrainian relations considering the activities of Proletkult (1917-1932) - proletarian cultural, educational and literary organization which was a constituent of People's Commissariat and the aim of which was a broad and comprehensive development of proletarian culture created by the working class.

Research objective is to investigate the RussianUkrainian relations considering the activities of Proletkult (1917-1932), find out the political conditions under which Ukrainian proletarian educational organizations developed.

Analysis of recent researches and publications. Among Russian researchers studying Proletkult we should mention M. Gorbunov, N. Yudin, L. Nikolayeva, M. Levchenko, L. Bulavka, A. Karpovand others. In Ukraine there is a few holistic studies of Proletkult organization's activities. Nevertheless, the issues of Russian-Ukrainian relations were not investigated in the works of researchers mentioned above that can be treated as a gap in historical and pedagogical science.

It was found out that it was the All-Ukrainian Proletcult that was distinguished by the acuteness of the national question concerning the use of the Ukrainian language, which resulted in the gradual Ukrainianization of its activities: Ukrainian studios opened, work was conducted in the Ukrainian language, curricula supplemented with courses on the study of the Ukrainian language, Ukrainian theaters were created, Ukrainians were active theaters

As the analysis shows, the use of the Ukrainian language was not denied, but it was possible in the context of the creation of a proletarian culture, not a national one, which caused a lot of controversy, ambiguous thoughts. In our opinion, this became the main reason for the decline of Proletkult in Ukraine. The pro-Ukrainian representatives of the Proletcultal organizations, for the most part, advocated the national character of creativity, the mother tongue as its basis; the object of their concern proclaimed the historical existence of the Ukrainian people.

They opposed the general tendency of Proletcult, which did not recognize the creativity of any nationality, and organized proletarian creativity was seen as a decisive stage for a truly universal.

Research presentation. Russian revolutionary social democracy during 1917-1920 realizing social and political transformations was following the Imperial mentality. It resulted in the fact that Ukraine received the status which was tantamount to cultural autonomy in the "united and indivisible" space of the Soviet Federation. The war and revolution were not the time for Ukraine to unite its people; they remained divided within two states.

However, even under these conditions the revolution made cultural activities fill with a sense of novelty, a consciousness of liberation from the old world and its limitations. The complex persistent questions arose and the main ones were such as which direction the Ukrainian culture should follow, what standards this culture should be based on, and what kind it should be in the whole. It was the time of searching and hope. Inspired by a sense of their own mission and growing audience, the writers, the artists and the scientists plunged into the creation of a new cultural universe with a great passion. In the field of education the global goal was also formed: the future of socialism was a new Soviet person.

During social upheavals (World War I, February Bourgeois Democratic Revolution and October Bolshevik Revolution of 1917, the civil war, National-Democratic Revolution in Ukraine, which caused the possibility to create a Ukrainian state, and a bitter defeat of Ukrainian National Republic) an intensive process of domestic cultural space self-organization developed together with the attempts of the institutionalization and structuring of modern Ukrainian culture under own state leadership.These processes occurred in difficult circumstances and were influenced by both internal and external factors. It is necessary to mention S. Kulchytskyi's work (2013) in which the author stated:

The Ukrainian Central Soviet must be remembered to act within the political space of Russia, which as an Entente member waged exhausting war against Central countries for more than two years. The Ukrainian revolution was a part of Russian but not an independent phenomenon. Although Ukraine formed its own political government, which began a national state-making process, its territory became the place of confrontation between Russian revolutionary and counter-revolutionary forces. The opposite parties fought not only against each other, but tried to strangle Ukrainian liberation movement.(p. 60).

With the Soviet power establishment the cultural processes in Ukraine occurred in the context of centralized policies of the Communist Party declaring the equal rights of all states or the members of newly formed federation in its normative documents. The Bolshevik leaders tried to control the process so that the ethnic revival would not be transformed into national, that is to say Ukrainians would enjoy the development of their language and culture without claiming to 
be independent from the centre of all other national states (Kulchytskyi, 2013, 83).

A week after the October Revolutionon the $15^{\text {th }}\left(2^{\text {nd }}\right)$ of November 1917 the Declaration of Russian Peoples' Rights was published and signed by the Chairman of the Soviet of People's Commissars V. Ulianov-Lenin and the People's Commissar on Nationalities Issues Y. Dzhugashvili-Stalin. The document emphasized that the 1st all-Russian Congress of Soviets in June 1917 had proclaimed the right of Russian peoples for free self-determination, and the 2d Congress of Soviets clearly and strongly confirmed this in alienable right. According to the decisions of these Congresses the Soviet of People's Commissars (SPC) formed such principles for its activity including nationality issues:

1) equality and sovereignty of Russian peoples;

2) the right of Russian peoples for free self-determination, including secession and formation of independent states;

3) abolition of all national and national-religious privileges and restrictions;

4) free development of national minorities and ethnic groups inhabiting the territory of Russia (Kulchytskyi, 2013, 184).

The reaction of the SPC to national countries sovereignty was offensive. On the $31^{\text {st }}\left(18^{\text {th }}\right)$ of January 1918 the $3 \mathrm{~d}$ all-Russian Congress of Soviets adopted "Declaration of rights of working and exploiting people". Its first item consisted of two parts and was in sidiously simple:

1) Russia was proclaimed as the Republic of soviets consisting of workers', soldiers'and peasants' deputies. All the power in the center and locally belongs to these soviets.

2) the Russian Soviet Republic was formed as the Federation of National Soviet Republics on the basis of voluntary uniting of free nations.

The heads of soviets would state that the Central Soviet used the national phrases and led anequivocal bourgeois policy, not recognizing Soviet power in Ukraine. As a result the contradiction between the declared statements and the real situation could be seen (Kulchytskyi, 2013, 185).

Among the four items describing national relations in the Program of the Russian Communist Party (of Bolsheviks) $(R C P(B))$, the first is relevant to our study as according to it,"Policy of different nationalities proletarians and half-proletarians cooperation was the basis for a joint revolutionary struggle against landowners and the bourgeoisie"(Kulchytskyi, 2013, 187). Such cooperation resulted in discrimination of the rights and freedoms of the Ukrainian proletariat by Russian proletariat, because the Russian language and culture were considered as progressive, proletarian, and leading, and the Ukrainian language was treated as peasant, a nationalist manifestation, and therefore, was unsuitable for building the culture of future - proletarian culture.

The fourth item explained who can express the nation will of separation. The working class was considered as a main doer in the process of transition from bourgeois to Soviet democracy (Kulchytskyi, 2013, 187). In the context of ensuring national equality proclaimed in the normative regulations the thesis of the fourth item can be again treated as contradictory. The Russian language was considered as a proletarian one on the contrary to the peasant Ukrainian language, so the discrimination of national culture could be clearly seen in real life.

However, despite of the official policy the development of the national liberation movement after the civil war gained undeniable momentum and it was impossible to control it. It provoked Lenin's resolution "On the Soviet Government in Ukraine" adopted on the Plenum of the Central Committee of the $\operatorname{RCP}(B)$ in November 1919. The resolution obliged all members of the Party to encourage free development of the Ukrainian language and culture. It stated the following:
Despite the fact that the Ukrainian culture (language, school, etc.) has been repressed by tsarism and exploiting classes of Russia for centuries, the Central Committee of the $R C P(B)$ makes it obligatory for every Party member to remove any barrier for free development of the Ukrainian language and culture using all possible means. The RCP(B) members should accept workers' right to learn the native language and speak it in all Soviet institutions on the territory of Ukraine, strongly oppose the attempts to push the Ukrainian language aside by artificial means and, vice versa, try to transform the Ukrainian language into a way of Communist education for the working masses (Lenin, 1974).

Despite such situation the state policy on the national culture was continuing as the government was afraid of the Ukrainian language acquiring the status of original on both state and all-Soviet levels. The actions taken were only the means of public attention distraction from establishing the dominance of the Russian language and culture.

In Bolsheviks surrounding the Ukrainian culture was considered as having a single meaning - a creation of bourgeois nationalist son the basis of their romantic and reactionary works - and it strongly affected the formation of the proletarian culture concept. After all, the situation that prevailed in the early $20^{\text {th }}$ century in Ukraine was characterized by the existence of deep contradictions between the autochthonous village and assimilated city population, between the Ukrainian peasantry and the Russian or Russified proletariat. Among the memoirs about the Ukrainian revolution there is a reasonable thought of $\mathrm{V}$. Zatonskyi, "Ukraine as a country did not exist for "soviets" and the parties of the city proletariat, for both the Bolsheviks and the Mensheviks (temperate members of the Party) as it did not exist for urban working class" (Zatonskyi, 1929). Only over time as a result of some confrontations it was possible to change a little the views of the Party and Soviet staff, and the declared Ukrainian Soviet statehood gradually began to acquire the relative recognition, the Ukrainian language and culture was given its almost official status (Parakhina, 2012, 23).

The Central Committee of the RCP(B) approved the decision of the 10th Party Congress (8-16 March 1921).The resolution of the Congress "Regular tasks of the Party on nationality issue" stressed that the task of Bolsheviks was to help "the working members of not Russian peoples" to develop and strengthen their court, administration, the economic bodies, governments where the native language was used and which were staffed by local personnel who knew the life and psychology of the local population, and to encourage the press, school, theater, clubs and general cultural institutions use native language in their development ("The 10th Congress of the RCP(B)", 1963, 603).

According to the Directives on Ukraine's nationality issue dated by October 17, 1922 and adopted by the Plenum of the Central Committee of the RCP(B) it was supposed to be "complete and absolute equality of the Ukrainian and Russian languages, a strong opposition to any artificial Ukrainization or Russification" and at the same time the elimination of barriers that could stop the natural development of the Ukrainian culture or that prevent the Ukrainian peasantry from accessing to the Russian culture; the struggle against all aspirations to make the Ukrainian language the means of separation and opposition of the Ukrainian workers and peasants to the Russian one shad to be conducted (Kasianov, 1992, 150).This illusion of languages "equality" was a part of the Soviet government's deliberate policy as the national liberation movement in Ukraine was raising, and although Bolsheviks had not many supporters among the intelligentsia, they pretended to encourage the equality of the Ukrainian and Russian culture and language to make the 
Party opposition weaker. Under this illusion of "equality" the Bolshevik theory of culture meant the destruction of "nationally limited" cultures.

The same idea was supported by $V$. Lenin who pointed to anegative role of national cultures in social progress:

It is possible for social democracy to proclaim directly or indirectly the slogan of national culture. Such slogan is misleading, since all economic, political and spiritual human lives are internationalized by capitalism. The international culture being systematically created by the proletariat of all countries can not include any "national culture" but embrace exclusively its democratic and socialist elements (Lenin, 1972).

$\mathrm{V}$. Lenin supposed the use of national culture only as a form of propaganda for Communist ideas or as a form of the national language for such propaganda.

In 1923 "contradiction between two cultures" began being actively supported. The Secretary of the Central Committee of the Ukrainian Communist Party(of Bolsheviks) (UCP(B) D. Lebed speaking at the Party conference in Kyiv said:

Theoretically we know that the contradiction between two cultures is inevitable. Due to certain historical circumstances in Ukraine the culture of the city is Russian, the culture of village is Ukrainian; to set the task to actively make the Party and the working class Ukrainian means to accept low culture of the village instead of the higher culture of the city (Kasianov, 1992, 75).

In early 1920 s the so-called theory of contradiction between two cultures was actively discussed by the Party leadership. The Russian culture was considered as leading one (because the speakers were of proletariat origin) and the Ukrainian culture was a retarded one (as only the peasantry in the countryside spoke it).This theory was proposed by the Secretary of the Central Committee of the UCP(B) D. Lebed who in the article "Some questions of the Party Congress" wrote that:

To set the task to Ukrainize the Party and therefore the working class will now be reactionary for cultural movement as nationalization, that is the artificial implanting of the Ukrainian language in the Party, means for the current political, economic and cultural relationships between the city and the village to accept low culture of the village but not the higher culture of the city (Kasianov, 1992, 75).

These views were supported by some members of the Party apparatus and some ordinary members who understood the necessity of the entire government structure being Ukrainized. Lebed's opponents realized that in the country, where $80 \%$ of the population was of Ukrainian origin, the government members had to speak the Ukrainian language. On the $7^{\text {th }}$ Conference of the UCP(B) (1923) concerning the issue of "two cultures" H. Rakovskyi stated that the government could not be neutral towards the Ukrainian culture and had to know it and help it to develop. M. Skrypnyk, V. Zatonskyi and others argued the "Lebed theory" too. As a result Lebed's points of view did not become the ideological directives and official policy but they certainly reflected the attitudes of a significant part of Russified members in state apparatus (Kasianov, 1992, 75).

A decisive step towards the implementation of the policy of Ukrainization was made at the $12^{\text {th }}$ Congress of the $\mathrm{RCP}(\mathrm{B})$ in 1923. It was after this Congress that Ukrainization was officially proclaimed as obligatory task for all Party members. In June 1923 the Council of People's Commissars of the USSR adopted Decree "On measures to ensure equality of languages and on assistance in development of the Ukrainian language".

It was quite often believed that the proletarian culture was national and international thus everything created for this culture had to be in the Russian language; the culture of Ukrainian peasants was bourgeois and therefore it was not appropriate to apply the Ukrainian language there. In the last decade of the Imperial period three social strata were distinguished - peasants, urban intellectuals and the proletariat that influenced the development of three approaches to national culture respectively.

Urban intellectuals were the most privileged part of the population under Russian cultural influence; they supported state policy as the dependence from Russian culture was historically caused by education, state public service, and ideological subordination. After the revolutionary changes this part of population was oriented to entire and indivisible Russia, total hegemony of Russian culture as a unifying factor in the Soviet country. They were quite often inimical to national manifestations, and the pursuit of national interests in so-called colonies of the Soviet Union.

The peasants were associated with folk traditions and customs developing over the centuries. The revolution in 1917 became a kind of signal for avoiding total subjugation in general and oppression of language in particular. Peasants' hostility to the city was clearly manifested during the civil war, which actually was economic destruction that provoked the intensification of struggle for national identity. As native speakers and experts in national traditions the Ukrainian peasants were the main supporters of the national revolution. However, as a result of different class contradictions they mainly paid attention to rather the social and economic than national and political slogans of the revolution. Being mainly of Russian origin the working class and the bourgeoisie on the contrary remained indifferent to the slogans of the national revolution (Kulchytskyi, 2013, 214).

The social origin of the proletariat was heterogeneous. The greater part of people was peasants by birth, consequently in terms of their national origin they were almost in distinguish able from the village natives. Such people work in urban areas, therefore hey became a subject of cultural influence of the urban intelligentsia and were introduced to Russian culture or in other words were industrialized. In Ukraine Russian people lived mostly in cities and the process of national liberation movement was slower there. P. Khrystiuk wrote, "Since the beginning of the revolution in Ukraine the city inhabitants have adopted either a hostile or neglect attitude to the Ukrainian Renaissance(Khrystiuk, 1921, 19).

The Communist ideology envisaged the unification of all society groups for socialist construction without considering nationality issue. In Ukraine during that revolution period the vast majority of workers had a typical attitude to nationality issue:

A working person, especially an employee "should be an internationalist", he does not consider the issue of language and culture as something important, it is a matter of the bourgeoisie, although nobody can interfere with any person's free usage of language as it was in tsar times. It is impossible to prevent some states in former Empire from developing their own national social order and even from forming separate and independent states. Everything a conscious worker should be interested in must be a social struggle against the landlords and the bourgeoisie. For this struggle being successful Russia should better remain the only country where the working class united by socialist slogans can fight against their enemy, and it is revolutionary internationalism, inherent in the working class in the period of revolutionary and destructive struggle against the former order (Lapchynskyi, 1927, 247).

The modern researcher M. Parakhina (2012) noted that the heterogeneity of the ethnic composition in the Ukrainian society, disparity between the rural and urban residents' cultural levels, population's low literacy rate, short age of professional staff, insufficient material base, lack of funding, influence of Russian culture and the need to oppose to great 
Russian chauvinism - all these factors formed significant barriers for creating Ukrainian culture in the 1920s. The situation was complicated by the fact that Russification policy in Ukraine having been realizing for several centuries resulted in the cities being not Ukrainized. However, the village residents preserved their ethnic and national culture: language, tradition, and so-called local colouring.

Nevertheless, the theory of two cultures which was also called "Lebed's" was convicted after 1923, when the government adopted the policy of "Ukrainization". The "theory of two cultures" after 1925 arose active discussion in literature and subsequently this issue turned from "literary" into political one and covered a range of urgent problems and prospects of development in the Ukrainian culture as a whole (Parakhina, 201, 33).

The process of Ukrainization began to fail in 1926. The reason for it may be found in Y. Stalin's letter which was written to L. Kaganovych on the $26^{\text {th }}$ of April 1926. When analyzing measures taken by Education People's Commissar of the Ukrainian SSR on Ukrainization Y. Stalin stated serious errors:

He confuses the Ukrainization of our Party and other staff with the Ukrainization of the proletariat. There is a necessity and opportunity to Ukrainize our Party, state and other apparatus personnel who serve the population. But it is impossible to Ukrainize the proletariat by government force. We cannot allow the Russian working masses to abandon the Russian language and recognize the Ukrainian culture and language as their own. This fact contradicts to the principle of nationality free development. This will not be national freedom but a form of national oppression (Stalin, 1949).

M. Skrypnyk, an ardent defender of Ukrainization, tried to solve the problem of culture formation taking into consideration clear Marks and Lenin's attitudes. He emphasized that there were only two ways of national culture creating: proletarian and bourgeois. The priority of class interests over national was the basis Skrypnyk's paradigm of the culture was built on (Stalin,1949). It was strongly believed that in the new state, which the proletariat brought a victory to, had to be a new culture - proletarian. The proletariat formed the vast majority of the urban population who was Russianspeaking, therefore proletarian culture had to be Russian.

It was obviously assumed that the Ukrainian culture, the roots of which were rural, would gradually infuse into Russian one. The culture that was traditionally identified with the countryside suddenly gained other vector of development, which led not only to aesthetic searches but also caused mental changes. Under these circumstances, the notorious theory of the "contradiction between two cultures" was widely spread in the Republic, its essence was discovered in the fact that "proletarian Russia" was opposed to "peasant Ukraine", and on this basis the conclusion was drawn that "Ukrainization" was not necessary because Russian (urban) culture would finally prevail over Ukrainian (rural) culture.

Most of public figures having orientation to national freedom took into account the customs and traditions of the Ukrainian people and believed that the formation process of proletarian culture should involve not only workers and city dwellers, but also peasants:

And such situation can be possible only when there will be no contradictions between the city and the country, when the town will be opened to the villagers and when the interests of both will be shared for the village and the town will be able to form strong structure. Yes, this is the only way to create a distinctive national art: go out of the depth sand to come to the people, understand their feeling sand their original views of beauty, genuinely love the surrounding nature (Burachek, 1920, 81).
Conclusions. Regarding nationality composition of the population on the territory of Ukraine within the studying period interesting statistic data and qualitative analysis can be found:

In Ukraine the same phenomenon can be seen everywhere: more than $92 \%$ of Ukrainians are farmers, $4-5 \%$ of them are workers, and others are artisans, small traders and service intelligentsia. Ukrainians cultivate lands but fishing, trade, science, culture and public administration do not belong to Ukrainians. Among capitalists there are only Russians, Jews, Poles and others. The city as a center of culture is not Ukrainian (Soldatenko, 1999, 170-171).

The issue of the Ukrainian language was solved by its ignoring or by its considering as a means for creating proletarian but not national culture. Such situation caused many arguments, controversial opinions, and what was most important, in our opinion, became the main reason of Proletkult decline in Ukraine.

Proletkult was established in Russia in 1917. In Ukraine these organizations were formed in 1919 when Soviet power was established. The main forms of educational work were clubs for workers, studios, proletarian universities, Proletkults for children, etc. Cultural and creative activities were realized in studios in such fields as literary, theatrical, musical, and visual arts.

Proletkult movement became widespread in Russia, but on the territory of Ukraine it was little distinguished. The main reasons for this were the dominance of the Russian language over Ukrainian; in fact, workers who were nonUkrainians had access to different organizations, but for the peasants - indigenous people - such access was not available. In Ukraine Proletkult failed to exist, but became a prerequisite for functioning of such proletarian literary organizations as "Plug", "Gart", etc. These tried to continue and to intensify the activities made by Proletkult organizations.

As a result, nationality issue, the issue of the Ukrainian language became crucial for Proletkult functioning in

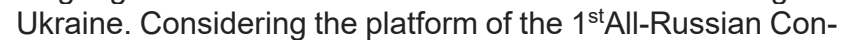
ference of cultural and educational organizations, focusing on the creation of proletarian culture as non-national international phenomenon, Proletkult appeared to be in opposition to the development of national liberation movement, manifestation of national consciousness. Proletkult organizations could not exist under pressure of the national liberation struggle, on the one hand, and official policy of the Soviet government and the Communist Party, on the other. Although some members of All-Ukrainian Proletkult had strong intention to Ukrainize its activities, Proletkult ideas were not supported by domestic scientists, artists, and public figures. The fact that the Presidium and All-Ukrainian Proletkult Council consisted mostly of Russian members should be paid attention to as it is obvious that All-Russian Council determined the content and direction of the activities performing in the Ukrainian organizations.

\section{References}

1. Burachek, M. (1920).Collective creativity and ways of national art. Art, $1,64-81$.

2. Kasianov, G.V. The Ukrainian Intelligentsia in 1920s - 1930s: Social portrait and historical destiny. (1992). Kyiv: Globus, Vik; Edmonton: Canadian Institute of Ukrainian Studies, 75-150.

3. Khrystiuk, P. (1921). Ukrainian Revolution. Historical materials of Ukrainian revolution history of 1917-1920, 19.

4. Kulchytskyi, S. (2013) The red challenge: History of communism in Ukraine - its development and ruin,1. Kyiv: Tempora, 60-83; 184-214

5. Lapchynskyi, G. (1927). National policy during ten years of Social Revolution. Life and Revolution, (5), 243-249.

6. Lenin, V.I. (1972). The report on nationality Issue. Complete Collection of Works, 23. Kyiv: National house of political literature publishing, 300-308.

7. Lenin, V.I. (1974). Resolution of Central Committee of the Russian Communist Party "Soviet government in Ukraine". Complete Collection of Works, 39. Kyiv: National house of political literature publishing. 
8. Parakhina, M.B. (2012). Main fundamentals of "contradiction between two cultures": problems of Russia and Ukraine's past and present times. Cherkasy: Cherkasy State Technology University, 23-33.

9. Soldatenko, V.F. (1999). Ukrainianrevolution.Kyiv: Lybid, 170-171.

10. Stalin, Y.V. (1949). To comrade Kaganovych and other members of Central Committee of the Communist Party (of Bolsheviks) of Ukraine. Collection of Works, 8. Kyiv: National house of political literature publishing in the Ukrainian Soviet Socialist Republic.
11. Sukhomlynska, O.V. (1996). Outlines of Ukrainian school history: 1905-1933. Kyiv: Zapovit, 7.

12. The 10th Congress of the Russian Communist Party (of Bolsheviks), March 1921: Verbatim report. (1963). Moscow: National house of political literature publishing, 603 .

13. Zatonskyi, V. The Fragments of memoirs about the Ukrainian revolution. (1929). Chronicle of Revolution, 4

Надійшла до редколегії 06.04.19

О. Кравченко, д-р пед. наук, доц

Уманський державний педагогічний університет імені Павла Тичини, Умань, Україна

\title{
УКРАЇНСЬКЕ ПИТАННЯ У ДІЯЛЬНОСТІ ПРОЛЕТКУЛЬТУ
}

У статті висвітлюються соціально-політичні умови, за яких функціонували пролетарські освітні організації 20-х років у контексті національного питання, а саме вивчення політичних рамок, що визначають статус української мови та культури в Україні. Питання про національність набуло вирішального значення в діяльності Пролеткульту - пролетарської культурно-просвітницької та літературної організації, метою якої стало широкий і всебічний розвиток пролетарської культури, створеної робочим класом. На відміну від Росії, ореанізації Пролеткульту в Україні не були поширені і перестали існувати через те, що національна мова та культура не були враховані, а контакти з селянами та корінними жителями непролетарського походження були обмежені.

Ключові слова: пролеткульт, робітник, культура, мова, політика, організація.

Удк 37.035:316.46(73)

V. Kudina, PhD (Pedagogical Sciences), Associate Professor Kyiv National Linguistic University, Kyiv, Ukraine

\section{THE CONTENT OF THE PRACTICAL TEACHERS' TRAINING IN HIGHER EDUCATIONAL ESTABLISHMENTS IN UKRAINE AND THE USA: COMPARATIVE ANALYSIS}

\begin{abstract}
The article is devoted to the problems of the practical teachers' training organization of future experts on teaching specializations. At the present period in the development of higher education pedagogy a lot of works of scholars and practitioners are devoted to the problems of teaching practice, such as: its role in the formation of prospective teacher's personality, the history of its development in the system of pedagogical education, the structure and content of the practical teachers' training, ways of its improving and take into account foreign experience in its organization. But the question of the practical training optimization of future experts and redistribution of time between the theoretical and practical training in favor of the second remains relevant. Organizational and methodological fundamentals of the teaching practice in higher education establishments are analyzed. Its role in the system of professional development of future teacher is revealed. The structure and content of teaching practice, the experience of its implementation over the last 50 years, the changes having taken place in the current conditions of pedagogical higher education transformation into the two- tier education system (the first (Bachelor) level and the second (Master) level) are analyzed. Characteristics of the teaching practice organization at higher education institutions of the USA and its structure and content are emphasized The experience of Professional Development Schools of future experts as a new model of the teachers' training in the context of pedagogical higher education reformation is provided.

Keywords: teaching practice, didactic practice, higher educational establishment, a student teacher.
\end{abstract}

Formulation of the problem. Today's new Ukrainian school requires a teacher, who can stem the decline in quality of education, who has obtained necessary competencies and who understands the way of realization of the competence-oriented content of school curricula. Not just a teacher, but the teacher-facilitator, the coach and the moderator for children in consideration of their individual educational needs. The teacher, who is able to provide the crosscutting educational process which forms values. So, "new school requires new teacher who might become the agent of changes", - mentioned in the National Strategy "The New Ukrainian School" [2].

In that regard, the development of the structure and content of the psychological, pedagogical and methodical training of prospective teachers is of particular importance. In the system of professional development of prospective educator the role of the teaching practice is significant. The practical teachers' training is recognized as one of the leading forms in the organization of educational process along with lectures, students' individual work and monitoring activities according to the Law of Ukraine "On Higher Education". The teaching practice is recognized as the special link between the theoretical training of prospective teachers and their work at educational establishments.

Analysis of recent researches and publications. At present in the development of higher education pedagogy the works of F. Gonobolin, N. Kuzmina, V. Slastonina,
G. Kodzhaspirova, V. Maiboroda, S. Vitvytska, G. Cherkas, V. Chepikova, Yu. Alferova, A. Vasyliuk, L. Pukhovska, $\mathrm{N}$. Onyshchenko and many others are devoted to the problem of the teaching practice role in the formation of prospective educator's personality, the history of its development as a component of the general teachers' training of future experts, the content of the practical teachers' training, ways of its improving and foreign experience of its organization.

Research presentation. Today the problem of improving the structure and content of practical teacher's training in the two-tier education system (the first (Bachelor) level and the second (Master) level) in the context of the European dimension remains urgent, but in practice it is still being unsolved.

During the last 50 years the structure and content of practical teachers' training in Ukraine have gone through the essential changes. In the 1970s the cross-cutting practical teachers' training of prospective teachers of different teaching specializations included all kinds of practice, such as: introductory, educational and professional. The introductory practice, as a rule, was conducted during the first and the second years of studying. Its purpose was to form professional motivation of educational activities and the system of knowledge of the chosen profession. The content of this practice included monitoring of teaching and educational process, analysis of lessons and educational events, and student teacher's active participation in the preparation and 